\title{
28-Nahçıvan folklor örneklerinde peygamberlerle ilgili konu ve motifler
}

\section{Çinara RZAYEVA ${ }^{1}$}

APA: Rzayeva, Ç. (2020). Nahçıvan folklor örneklerinde peygamberlerle ilgili konu ve motifler. RumeliDE Dil ve Edebiyat Araştırmaları Dergisi, (Ö8), 357-367. DOI: 10.2900o/rumelide.814291.

\section{$\ddot{\mathbf{O} z}$}

Makalede peygamber anlayışı incelenmiş, onların işlenme sıklığı belirlenmiştir. Araştırma sırasında peygamber kavramının tüm folklor türlerinde ortaya çıtığını görmek memnuniyet vericidir. Folklor metinlerinde peygamberlerin sadece isimleri geçmemekte, aynı zamanda becerileri ve hizmetleri de yansıtılmaktadır. Öyle ki, Hızır peygamber darda olana yardım etmeyi ve aşıkları birleştirmesi ile folklorda özel yere sahiptir. Süleyman peygamber de hayvanların dilini bilmesi ile, Musa peygamber asası ile, Yunus peygamber balık tarafından yutulması ile, diğer peygamberler de olumlu karakterleri ile folklor metinlerinde yer alır. Folklor metinlerinde bahsedilen $\mathrm{Hz} \mathrm{Adem}, \mathrm{Hz}$ Nuh, Hz Muhammed Mustafa, Hz Musa, Hz Yakup, Hz İbrahim, Hz Yusuf, Hz Davut, Hz Süleyman, $\mathrm{Hz}$ İsmayıl, $\mathrm{Hz}$ Hızır ve diğer peygamberler çalışmamıza dahil edildi. Not edelim ki, metinlere peygamberlerin adı çeşitli isimlerle yansır. Örneğin, Nuh peygamberle ilgili metinlerde "Nuh", "Hazreti Nuh", "Nuh Nebi” gibi ifadelere rastlanır. Hızır peygamberin adı da "Hızır İlyas”, "Hızır peygamber" gibi isimleri ile geçmektedir. Araştırma sırasında isimleri geçen peygamberlerin hemen hepsinin adı, kutsal kitabımız olan Kur'an-ı Kerim'de de geçmektedir. Makalede, Nahçıvan, Türkiye ve Kur'an-ı Kerim'den örnekler gösteren bir dizi karşılaştırmalı analizler yapılmıştır. Yapılan araştırmalar da kanıtlamaktadır ki, eski ve büyük tarihe, hem de zengin kültüre, folklora sahip olan Türk halkları, her zaman kendi milli-manevi değerlerini, folklorunu, eski geleneğini koruyarak bugüne getirmiş ve bundan sonra da bu zengin mirası koruyarak gelecek nesillere ileteceklerdir.

Anahtar kelimeler: Nahçıvan, Kur'an-ı Kerim, Türk, folklor, peygamber

\section{Consepts and motives associated with the prophets in the folklore of Nakhchivan}

\begin{abstract}
The concept of the prophet were detailed in the article and a number of analyzes were carried out. Fortunately, examples related to the prophet can be found in all genres. Folklore texts reflect not only the names of the prophets, but also their abilities and merits. Thus, the Prophet Khidr is included in folklore, helping those in need and uniting lovers. Prophit Solomon is known for his ability to understand the language of animals, prophit Moses for his stick, prophet Johan for being swallowed by fish and other prophets are also mentioned in folklore texts for their positive characters. In folklore texts, Adam, Noah, the prophet Muhammad Mustafa, Moses, Jacob, Ibrahim, Johan, Jabrail, David, Solomon, Ismail, Khidr and other prophets were analyzed. It should be noted that the names of the prophets are referred to in the texts differently. For example, in the texts about the prophet Noah, we come across the names such as Noah, Hazrati Nuh and the Prophet Noah. The name of the prophet Khidr is also expressed as Khidr Ilyas, the prophet Khidr.
\end{abstract}

Dr., Azerbaycan Milli Bilimler Akademisi, Nahçıvan Bölümü, Folklor Şubesi (Nahçıvan, Azerbaycan), cinarerzayeva@yahoo.com.tr, ORCID ID: 0000-0003-0655-9342 [Makale kaylt tarihi: 07.09.2020-kabul tarihi: 20.11.2020; DOI: 10.29000/rumelide.814291

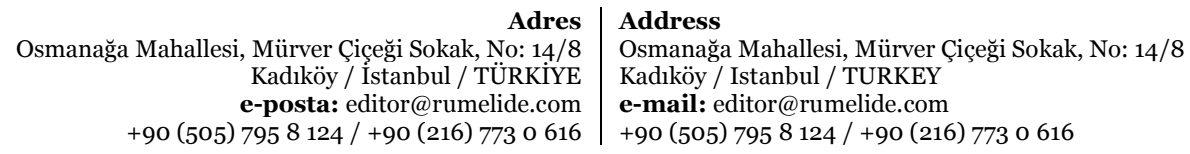




\begin{abstract}
Almost all the prophets mentioned in the analysis are named in our holy book, the Holy Qur'an. A number of comparisons are made in the article, examples from Nakhchivan, Turkey and the Holy Quran are given. Research also proves that the Turkic peoples, having an ancient and great history, as well as rich culture and folklore, have always preserved their national and spiritual values, folklore, past traditions and will pass them on to future generations. ...
\end{abstract}

Keywords: Nakhchivan, Holy Quran, Turkey, folklore, prophet

\title{
Giriş
}

Peygamberlerle ilgili konular halk edebiyatında yaygın olarak kullanılmıştır. Önce peygamber kelimesinin manasına bakalım. Sözlükteki anlamı Farsça kökenlidir ve “Tanrı'nın talimatlarını bildiren ve yorumlayan kişi; ikinci anlamı gelecekten haber veren biridir ve üçüncü anlamı ise saf, kutsal, kutsal adam" (Orucov vd. 2006. 588). Kur'an-1 Kerim, Azhab suresinin 21. ayetinde peygamberimiz ile ilgili olarak da şöyle buyurulmaktadır: “Andolsun, Allah'ın Resûlünde sizin için; Allah’a ve ahiret gününe kavuşmayı uman, Allah’ı çok zikreden kimseler için güzel bir örnek vardır” (Altuntaş vd. 2011. 464). Peygamberle ilgili Kur'an-1 Kerim'in bir çok ayetlerini örnek olarak göstermek mümkündür. Peygamber kavramı Kuran ve hadislerle sınırlı olmayıp sözlü edebiyatta pek çok türde de karşımıza çıkmaktadır. Bu nedenle yetenekleri, hizmetleri ve özellikleri folklorda geniş ölçüde yansıtılmaktadır. Örneğin muhtaçlara yardım eden Hızır peygamber folklorda özel bir yere sahiptir. Süleyman peygamber hayvanların dilini bilmesiyle, Musa peygamber asası ile, diğer peygamberler de birbirinden farklı olumlu karakterleriyle folklor metinlerinde yer almaktadır.

$\mathrm{Bu}$ makale, folklor metinlerinde peygamberin konu ve motiflerini incelemekte ve gelişme sıklığını belirlemektedir. Ayrıca Kur'an-ı Kerim'den örneklerle bir takım karşılaştırmalar da vardır. Aynı zamanda Türk folkloruna da değiniliyor ve karşılaştırmalar yapılıyor. Şimdi de peygamberlerle ilgili halk edebiyatı örneklerine ve mukaddes kitaptaki kıssalarla karşılaştırmalarına bakalım.

\section{Adem peygember}

Adem peygamber İslam'dan önce de bize malumdur. Bütün insanlar ilk olarak onun yaratıldığını ve Havva'nın onun kaburgalarından doğduğunu bilir. Adem peygamberin kimliği şöyle açılanmaktadır: “Tevrat ve Kuran'da Allah'ın yarattığı ilk insan ve insan ırkının ulu babasıdır. Havva'nın kocası, Habil'in, Kabil'in ve Şeyis'in babası. Allah'a itaatsizlik edip iyilik ve kötülük ilim ağacının meyvesini tattıktan sonra Cennet'ten kovuldu"(Azerbaycan vikimediaçıları, 2020). Adem peygamber hakkında bir takım düşünceler de karşımıza çıkıyor. Örneğin, Yahudilere göre, "Adem ve Havva, tüm insan imajını yansıtır, tam bir insan ilişkileri yelpazesi gösterir ve hikayeleri insanlığın tarihsel bir örneği olarak kabul edilebilir" (Azerbaycan vikimediaçıları 2020). Hristiyanlığa göre başka bir açıklama yapılır: "Adem, insanın Tanrı ile ilişkisinin bir sembolüdür. Mutlak doğruluğu ve kişisel ölümsüzlüğü vardı, ama yoldan çıktı̆̆ı için hepsini kaybetti. Bu kusur onun gelecek neslini yani insanları etkiledi” (Azerbaycan vikimediaçıları, 2020). Adem Peygamber hakkındaki fikirlerin çoğu Kur'an-ı Kerim'de de bulunmaktadır.

Kuran-ı Kerim'de sözü edilen Hz. Adem ile ilgili bu düşünceler folklor metinlerine de yansımıştır. Folklor türlerinde Hz. Adem hakkında çeşitli sözlere rastllyoruz. "Emrah" destanı'nda bahsedilen örneğe bakalım: Örneklere geçmeden belirtelim ki, Türkiye Türkçesine çeviri zamanı örnekleri folklor

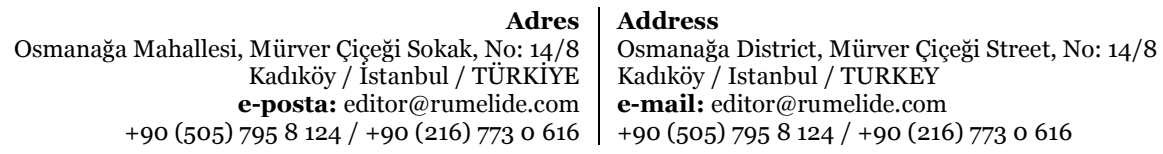


metinlerinden aldığımız gibi veriyoruz. Yalnız bazı harfleri Türkiye Türkçesine uygun değiştirdik. Mesela, " $ə$ ", " $q$ ", “ $x$ ” harflerini.

Evvel sana geldi Ademü Hevva,

Beş gün konak oldu sende bineva,

Öldürdün Habil'i, saldın bir dava,

Düşdü arasına nahak kan, hanı? (Ceferli vd. 2011, 454)

Kitaplarımızda Adem peygamber ve Havva annemizle ilgili bir takım hadislere de rastllyoruz. Hadislerden biri Adem'i cennetten götürenin Havva olduğunu belirtir. Bu hikaye Nahçıvan folklor metinlerinde biraz farklı bir biçimde yer almaktadır. Örneğin:

"Şeytan tavus kuşuna dedi ki, meni apar Ademinen Hevvanın yanına.

Dedi:

- Apara bilmerem, amma burda biri var, eliyer.

Getdi ilanı çağırdı. İlan ağzını açdı. Seytan ismiezem okuyub girdi bunun karnına. İçeri girib Ademinen Hevvaya pislik eledi, buğdanı yedirdib cennetden kovdurdu. Allah ilanın kanadın tökdürdü, özün de o cilde saldı, ilan başladı sürünmeye” (Ceferli vd. 2012, 72).

Bu örnek, Adem ve Havva'nın Cennet'ten kovulmasını gösteriyor. Ayetlerimizde ağacın meyvesini yiyerek cennetten kovulduğu bilinmekte, örnekte ise buğday yiyerek cennetten kovulduğu yazılıyor. Gösterdiğimiz örnek halk edebiyatına ait efsane olduğu için bazı değişiklikler ve farklılıklar kendini göstermektedir. Tabii ki, daha sonra yaptıklarından pişman olup tövbe ediyorlar. Bu kutsal kitap, Kuran-1 Kerim'de de anlatıllyor. Bakara suresinin 37. ayetinden okuyoruz: "Derken, Âdem (vahy yoluyla) Rabb'inden birtakım kelimeler aldı, (onlarla amel edip Rabb'ine yalvardı. O da) bunun üzerine tövbesini kabul etti. Şüphesiz O, tövbeleri çok kabul edendir, çok bağışlayandır" (Altuntaş; Şahin. 2011, 9).

Aşık edebiyatında Adem peygamberin adı geçen örneğe bakalım:

Kurbani der, yoktur sözün çaresi,

Neçe ildi yerle göyün arası?

Hazreti Adem'in lele babası,

Çiyninin ebası ne renkteydi? (Ceferli vd. 2011, 436)

Adem peygamberin adı emek türkülerinde de geçmektedir. Şarkılardan okuyoruz:

Saya geldi gördünüz?

Salam verdi, aldınız?

Saya kimden kalıp?

Adem atadan kalıb (Ceferli vd. 2010, 339).

Adem peygamber ilk insan olduğu için herkes ona Adem ata da diye müracaat ediyor. Gösterilen örnekten de görüyoruz. Bu "Adem ata" müracaatına Türk folklorunda "Manas" destanında da rast geliyoruz.

Birlikte dolaşıp gezsen Bakay

Adem Ata'yı Havva Ana'yı

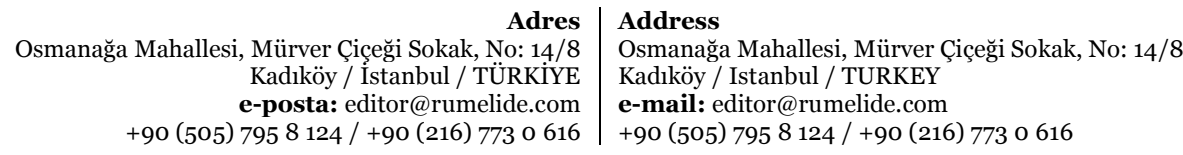


Doğduğu vatanını bilici eyle

Sağ yanına Oysu! Ata muska eden Bakay

Sol yanına Koca Hıdır dua eden Bakay (Şükrü, 2004. 107)

Bu da onu gösteriyor ki, sadece Azerbaycan halk örneklerinde değil, digger Türk folklorunda da Adem peygamber bir imge olarak kullanılmaktadır.

\section{Nuh Peygamber}

Nuh peygamberle ilgili kutsal kitabımız olan Kuran'da pek çok ayet vardır. Araf suresinin 59. ayetinde Nuh peygamberle ilgili şöyle söyleniyor: "Andolsun, Nûh'u kendi kavmine peygamber olarak gönderdik de, "Ey kavmim! Allah’a kulluk edin. Sizin için O’ndan başka hiçbir ilâh yoktur. Şüphesiz ben sizin adınıza büyük bir günün azabından korkuyorum” dedi (Altuntaş; Şahin. 2011. 172). Kutsal Kitabımızın birçok ayeti Nuh peygamberle ilgili düşünceleri açıllıyor. Örneğin Hud suresi. Bu surenin ayetlerinin çoğu Nuh peygamberi anlatıyor. Bu kitapta ifade edilen fikirlerden bazıları sözlü edebiyata da yansımıştır. Yani halk edebiyatında Nuh hakkında birçok efsane ve rivayetler var. Örneğin, "Nuh Tufanı" efsanesinden bir alıntı:

"Hazreti Nuh bir gece yatmıştı, alemi-vakiede gördü ki, buna teklif getirdiler, ya Nuh, yakın vakitde dünyanın üzünü su alacak. Gedirsen meşeden ağaçlardan kesirsen, bir gemi hazırlayırsan. O vakıt Hazreti Nuh eleyhissalam buyurdu: Ey menim Rebbim, men ustalık bilmirem ki, men dülgerliği bilmirem ki, men gedem ağaç kesem, gemi hazırlayam.

Allah-Taala'dan nida geldi: - Ya Nuh, sen get ağaçlardan kır, geminin hazırlanması ile işin olmasın.

Hazreti Nuh'a uykuda ki, bele deyildi, seher baltasını koydu çiynine, başladı meşeye yol eledi. Getdi ağaçların harda düzleri vardı, kesdi, kabıklarını soydu, yığdı bir yere. Geceni geldi eve, seherisi getdi gördü bunlar yonulup, çivilenmiş.

Bir müddet bu işi ile meşkul oldu, bir günleri gemi hazır oldu.

Dedi: - Ey menim Allahım, gemini hazır eledim. Ya Allah, men ne bilerem ki, dünyanın üzünü ne vakit su alacak, men gelim, bu gemiye sahiblik eliyim.

Bu vakit Allah-Taala'dan nida geldi: - Ya Nuh, o vakit ki, sen çölde ekin ekessen, arvadın evde çörek yapacak. Nevakit ki, o yanan tendirden su kalkdı, o vakit bilginen ki, vakit gelib çatıb” (Ceferli vd. 2011, 6).

Fikir tam anlaşılsın diye metinden örneği geniş şekilde gösterdik.

Bu rivayetin Kur'an-ı Kerim'de verilen bir ayete dayandığını düşünüyoruz. Ankebut Suresinin 14. ayetinden okuyoruz: “Andolsun, biz, Nûh'u kendi kavmine peygamber olarak gönderdik. O da dokuz yüz elli yıl onların arasında kaldı. Neticede onlar zulümlerini sürdürürlerken tûfan kendilerini yakalayıverdi” (Altuntaş; Şahin. 2011. 437).

Nahçıvan folklor metinlerinde de Nuh'un Gemisi hakkında bir dizi efsane ve mite rastlıyoruz. "Nuh'un Gemisi" efsanesinden okuyoruz:

“Eski zamannarda bir karı yer üzünü su alacağını eşidir ve Nuh peygambere yalvarır ki, onu da öz gemisine götürsün. Karı bir balaca çörek pişirip özü ile götürmek isteyir ve tendirde onu uyku tutur. Su karının tendirinden kalkıyor. Peygamber bütün canlıların hepsinden bir cüt gemiye alır. Gemi kalkır, onun bir parçası İlandağ'a deyerek düşür. Sonra bir haylı irelide gemi yene başka dağa çarpır ve bir tahtası düşür” (Ceferli vd. 2010, 55).

Gemi hakkında Kur'an-ı Kerim'in Şuara Suresi, 119. ayetinde verilmişdir: "Derken biz onu ve beraberindekileri dolu geminin içinde (taşıyıp) kurtardık” (Altuntaş; Şahin. 2011. 408).

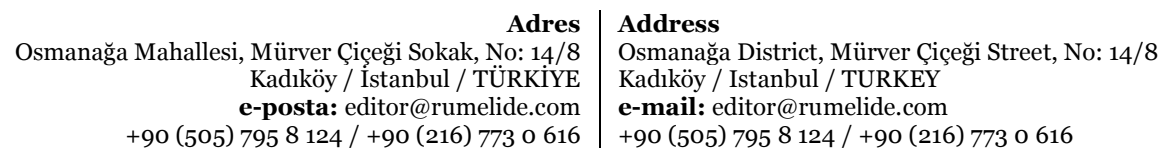


Araştırma yaptığımızda, tüm bu efsanelerin ve rivayetlerin Kuran-ı Kerim surelerine dayandığını açıkça görmekteyiz. Çünkü efsanelerden bahsettiğimizde, her mitin ve efsanenin gerçek bir temeli olduğunu not ediyoruz. Yani, herhangi bir gerçeğe dayanarak çeşitli efsaneler ortaya çıkıyor.

Araştırma sırasında Hazreti Nuh ve Nuh Nebi, gibi ifadelere de rastllyoruz. Örneğin:

"Deyilene göre, Nuh Nebi bilirmiş ki, tufan kopacak, dünyanın üzünü su alacak. Odur ki, böyük bir gemi düzeltmek kararına geldi” (Ceferli vd. 2010, 69).

Yukarıdaki örnekte Hazreti Nuh ifadesiyle karşılaştık. Onu da belirtmek isteriz ki, Nahçıvan'da Nuh peygamberin mezarı vardır.

\section{Musa Peygamber}

Herkese malumdur ki, her peygamber, kendisine verilen güç ile bilinir. Musa peygamber de "asa"sı ile tanınır. Kuran-ı Kerim'de Hz.Musa hakkında birçok ayet görüyoruz. Asa ile ilgili sirri ilk olarak kutsal kitabımızdan okuduk. Bakara Suresi, 6o. ayet: "Hani, Mûsâ kavmi için su dilemişti. Biz de, "Asanı kayaya vur" demiştik, böylece kayadan on iki pınar fışkırmış, her boy kendi su alacağı pınarı bilmişti. "Allah'ın rızkından yiyin, için. Yalnız, yeryüzünde bozgunculuk yaparak fesat çıkarmayın” demiştik" (Altuntaş; Şahin. 2011.12). Musa peygambere mahsus olan "asa"nı, dine imanı ve sevgisi olan halk folklor metinlerine de yansıtmıştır. Örneğin:

Peyğemberimiz Musa'dl,

Eline alan "asa"dı.

Bu gelen, adın Hasadı.

Koyun menim yarım gelsin,

Koyun menim gülüm gelsin (Ceferli vd. 2011, 442).

Efsane ve rivayetlerde de Musa peygamberle bağlı hadiselere rast geliyoruz:

"Men bele eşitmişem ki, Musa peyğember heyvan otarırmış. Musa peyğember çoban olubdu. Möhkem yağış yağır. Bu gelib girir dokkuzdon kolunun altına, bunun da yarpakları küçük yarpaklardı. Musa peygamber bu ağaçın altında möhkem islanır. Baktı ki, yakınlıkta bir ağaç var, yarpağı çokdu. Ağacın altından çıkanda deyir:

-Seni görüm dokkuz defa kabuğun soyulsun.

İndi deyilişe göre, ilde dokkuz defa onun gövdesinin kabuğu soyulur. Sonra bu ardış ağaçının altına girir, yağışdan korunur. Ona da deyir:

-Seni görüm hemişe yaşıl olasan” (Ceferli vd. 2012, 74).

Musa fikrinin açılı̆̆ga kavuşması için tam metni vermemiz gerekiyordu. Örneklerde hem Musa'nın asasını, hem de sözlerinin gücünü görüyoruz. Bu, peygamberlerin gücünü bir daha doğrulamaktadır.

\section{Hz. Hizir}

Hz. Musa zamanında Hz. Hızır'ın yaşadığı birçok kaynakta belirtilmektedir. Kur'an-ı Kerim'de varlığından tam olarak bahsedilmemesine rağmen, ona bir gönderme olduğu çeşitli ayetlerde araştırılmaktadır. 
Nahçıvan folklor metinlerinde adı geçen Hz. Hızır ile ilgili birçok söz vardır. Hz. Hızır, muhtaç olanlara yardım ettiği için mitolojik bir obraz bile olmuştur. Araştırmalar folklor metinlerinde Hz. Hızır'ın adının daha yaygın olduğunu göstermektedir. Belirtelim ki, Hıdır İlyas, Hıdır peygamber, Hızır İlyas gibi isimlerine de folklor metinlerinde rastlıyoruz. Bazı araştırmalarda Hızır onun lakabıdır. Ve şu şekilde açıklanmaktadır:

"Hızır lakabıyla meşhur olmasının sebebi, kuru bir yere oturup kalktı̆̆ı zaman, oranın yeşerip yemyeşil olmasından dolayıdır. Sahîh-i Buhârî'de bildirilen bir hadîs-i şerîfte Peygamber efendimiz; "Hızır (aleyhisselam), otsuz kuru bir yerde oturduğunda, o yer birdenbire yemyeşil olur, peşi sıra dalgalanırdı" buyurdu. Musa aleyhisselamla görüşüp yolculuk yaptı. Fakat vefatından sonra rûhu insan şeklinde gözüküp, garîblere yardım etmektedir”(Dinimiz islam, 2020) Aynı zamanda destanlarda da birçok sevenlere yardım ettiğini görüyoruz. Buna Azerbaycan'da toplanan destanlarda ve diğer Türk halklarının destanlarında sıkça rastlanır. Hemen hemen tüm destanlarda Hızır İlyas aşıklara yardım etme, onları birleştirme ve bazı durumlarda ölüleri diriltme görevini yerine getiriyor. "Arzu ve Kamber" destanında aşıları diriltme misyonunu görüyoruz:

“Arzu ile Kenbere bir serdaba tikdiler. Arzu ile Kanberin meydini serdabenin kenarına apardılar. Meydleri defn elemek isteyende Hızır gelib çıkdı, yüksekten dedi:

-Kenarlaşın, bu aşık-meşuk ne günahın sahibidi ki, bunları diri-diri defn edirsiniz.

Dediler:

-Ay canım, ne danışırsan, bunlar üç gündür ki, ölübler.

Hızır Arzu ile Kanber'in meyidlerinin lap yanına geldi, dedi:

-Ey aşık, meşuk uykuya kalmışsınız. Daha yatdığınız yeter, kalkın ayağa.

Söz ağzından kurtaran kimi Arzu ile Kanber hapşırıp ayağa kalkdılar, Hızır da geybe çekildi” (Azerbaycan destanları 2005. 246).

Belirtelim ki, bu destanın diğer Türk halkları varyantının çoğunda da Hz. Hızır yetişip aşikleri kurtariyor.

Hz. Hızır'ın mukaddes olması da folklor metinlerine yansıyor. Halk arasında düşünülüyor ki, o mukaddes insandırsa, demek ki, onun ayağının değdiyi toprak da mukaddesdir. "Senem Cadı" masalından okuyoruz:

"Hıdır peygamber yeriyende Senem Cadı onun ayağının altından bir ovuç toprak götürür. Desmala bağlayır, koyur cibine"... sonra "Hıdır peygamberin ayağının altından götürdüyü toprağı kızın yarasına sürtür. Kı özüne gelir (Ceferli vd. 2011, 136).

Alkışlarda (dualarda) da Hızır adına rastlıyoruz:

Hızır yolda yoldaşın olsun.

Birinin işi zora düştüğünde "Yetiş ya Hızır" diye de sesleniyor. Bu deyim Türkiye folkloruna da yansımıştır. Hatta, Türkiye filimlerinde de rastımıza çıkıyor. Örneğin: "Eskiya dünyaya hökümdar olmaz" dizisinde Hızır Çakırbeyli'nin "Yetiş ya Hızır” demesi ile zor bir işin üstesinden kolayca gelmesi de dikkat çekiyor.

Hadislerde Hızr'ın vefatından sonra bile insanlara yardım ettiğini okuyoruz. Yani efsanevi bir imge olarak ölümsüzleştirilmiştir. "Ziyad ve Şevket” destanında da şu fikirle karşılaşıyoruz: 
İskender atlandı, çıkdı zülmatdan,

Hızır gedib içdi abı - hayatdan.

Düşdü kılınçtan, giyimden, atdan,

Süfreni onlardan suvar deyerler (Ceferli vd. 2010, 489).

Hızır peygamberle ilgili bir çok örnek vardır ve biz makalenin hacmini göz önüne alarak gösterilen örneklerle yetiniyoruz.

\section{Davud peygamber ve oğlu Süleyman peygamber.}

Davut peygamber ve oğlu Süleyman, Tanrı'nın yeryüzüne gönderdiği peygamberler arasındaydı. Kur'an-ı Kerim'deki Neml Suresi'nin pek çok ayeti Hz. Süleyman (a.s.)'dan, özellikle 15 ve 44. ayetleri Davut ve Hz. Süleyman (as)'a atıfta bulunmaktadır. Neml Suresi'nin 15-16. ayetlerinde okuyoruz:

“Andolsun! Biz Dâvûd'a ve Süleyman'a ilim verdik. Onlar, "Hamd, bizi mü’min kullarının birçoğundan üstün kılan Allah’a mahsustur” dediler. 16. Süleyman, Dâvûd’a varis oldu ve "Ey insanlar, bize kuş dili öğretildi ve bize her şey verildi. Şüphesiz bu, apaçık bir lütuftur”, dedi" . (Altuntaş; Şahin. 2011.416).

Kuran'da Davut ve Hz. Süleyman hakkında yansıtılan şeylerden bazıları, örneğin Süleyman'ın Davut'tan miras kaldığı gerçeği, kuş dilinin bilmesi vb. folklor metinlerine de yansımıştır.

“Süleyman peygamberin masalı”ndan okuyoruz:

“Cebrayll Davud peygamberin yanında nazil olur. Deyir ki, Davud peygamber, gam eleme, Allah sene ele bir oğul verecek ki, senin 40 oğluna evez olsun. Yaşı ötmüşs olsa da, Allah-Taala Davud peygambere Süleyman adlı bir oğul verir” (Ceferli vd. 2012, 324).

Süleyman peygamber gösterilen ayetde ve bir çok hadislerde kuşların dilini bilmesi ile tanınır. Süleyman peygamberin bu yeteneğine "Baykuş efsanesi”nde de rast geliyoruz:

"Hazreti Süleyman bütün canlıların hökmdarı olduğundan emr edir ki, bütün kuşlar yığılsın. Cemi kuşlar az geçmir ki, Hazreti Süleyman'ın yanına toplaşır” (Ceferova. 2012, 94).

Bu örnek, Süleyman'ın canlıların hükümdarı olarak tasvir edilmesi, kuşların dili hakkındaki bilgisini doğruluyor.

Başka bir örneğe göz atalım:

Oğlan kemendi atdı atın boynuna. At iki elleri üstünde kalkdı göye, oğlanı çekdi, oğlan düz düşdü onun beline. At bir de kalkdı ki, onu vursun yere, oğlan dedi:

- Ay at, Süleyman aşkına dayan!..

At Hazreti Süleyman'ın adını eşitcek dayandı. Oğlan onu dehne çilov vurub, başın dönderdi (Ceferli vd. 2010, 177).

Bu örnek, Süleyman Peygamber'e olan hayvan sevgisini göstermektedir. 


\section{Yunus peygamber}

Malumdur ki, herkesin bir yaşamı olduğu gibi, peygamberlerin de kendi yaşamları vardı ve her peygamber bir şekilde imtihan edildi. Bu peygamberlerden biri de bir balığın karnında kalarak imtihan edilen Yunus peygamberdir.

Belirtelim ki, dini konuların folklor metinlerinin yaranmasında büyük etkisi olmuşdur. Kuran-ı Kerim'in Enbiya suresinin 87. ayetinde - "Balık Sahibi'ni de hatırla. Hani o kavmine kızarak gitmiş; bizim kendisini hiçbir zaman darda bırakmayacağımızı zannetmişti. Balığın karnına girince karanlıklar içinde: "Senden başka ilâh yoktur. Sen her türlü kusurdan, eşi-ortağı olmaktan uzaksın. Şüphesiz ben kendine yazık edenlerden oldum” diye yakardı”. Yunus peygamberle ilgili Kutsal kitabımızda yer alan bu kelamlar folklor motivlerinde kendini göstermektedir. Örneğin,

- Ey balık, Yunus iman ehlidir, özü peygamberdir. Men onu sene yem gibi vermirem. Koy, bir müddet senin karnında dustak olsun. O, menim zaminimdir. Bir vakit gelecek ki, onu senden taleb edeceğim.

Yunis peygamber ise, balığın karnında Allaha dua etmekle meşgul olur.

Peygamberin sesi göyün katlarına da gidib çatır (Ceferova. 2012, 77).

Nahçıvan folklor örneklerinde bir çok peygamberin ismi geçiyor. Onlardan Hz Yusuf, İsa peygamber, Siyakut peygamber vb. isimlerini göstere biliriz. Fakat adlarını çektiğimiz bu peygamberlerle ilgili metinler Nahçıvan folklor türlerinde çok değil. Bu peygamberlerle ilgili bir kaç örneğe göz atalım.

Belirtelim ki, Yusuf peygamberin hayatı hakkında pek çok efsane vardır. Hepimiz yaşadığı hayatı ve Zuleyha'nın ona olan sevgisini biliyoruz. Ne mutlu ki, folklor metinleri bazen peygamberlerin hayatlarını aynı şekilde yansıtmaktadır. Ya da yaptıkları her şeyi peygamberlerin hayatına benzetiyorlar. Bunu aşă̆ıdaki örnekte görebiliyoruz.

“Oğlan şirin uykuda yatmışdı. Deyerler ki, seherin uykusu ölümden beterdi. Kardeşler onun ayağını kendirnen berk sarıyı getirib Yusuf gibi bir kuyuya salırlar" (Ceferli vd. 2010, 180).

$\mathrm{Bu}$ örnekte Yusif peygamberin kuyuya atılması hatırlanıyor. Yusif peygamber de kardeşleri tarafından kuyuya atılmış ve kervan tarafından bulunmuştur.

İsa peygamberin de ismi folklor örneklerinde çok fazla değil. Herkese malumdur ki İsa peygamber babasız doğmuş ve beşikteyken konuşmaya başlamıştı. Ölüleri diriltme gücüne sahipti. İncil kitabı ona verildi. Şimdi de İsa peygamberin adının geçtiği folklor örneklerine bakalım. Manilerden okuyoruz:

Karayam Kamber gibi,

Müşk ile enber gibi.

Karanı ele severler,

İsa peygamber gibi (Ceferli vd. 2010, 362).

Siyakut peygamberin adı Nahçıvan'da toplanan efsanelerde geçiyor.

Keçmişde Siyakut peygamber gelir adamları din yoluna çă̆ırır. Yolunu azan adamlar olur. Siyakut peygamberi ordan kovurlar. O, Ordubad'ın önünde, Araz'ın o tayında Siyarı kendi deyirler, hemen peygamberin adınadı, ora gedip. Peygamberi öldürüp basdırıplar torpağa. Araz bir ay kan akmış. Rüzgar başlamış, tufan kopmuş. Kotam kapısından Dereli'ye kadar, Elince çayına. İran'da haber

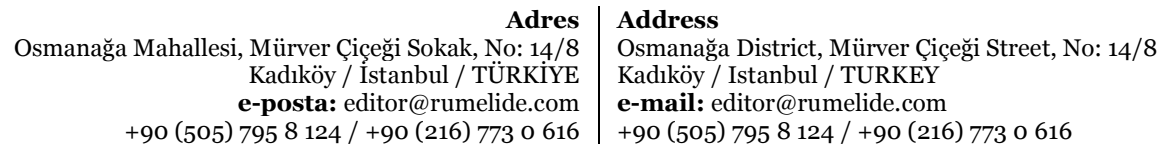


tuturlar ki, buraları rüzgar dağıtır. Ağıllı, dünyagörmüş kocalar olup. Gelip soruşurlar ki, siz ne iş görmüsüz. Peygamberi öldürdüklerini eşidende deyirler ki, kurban kesin, Allaha dua edin (Ceferli vd. 2012, 63).

Örnekten göründüğü gibi Siyakut peygamber de insanları din yoluna çağırıyor. Fakat bu onun hayatının sonu oluyor. Ve baş veren tufan, rüzgar bir daha her kese gösteriyor ki, Allah'ın elçisi Allah için deyerli varlıklardır. Peygamberlere kötülük yapan her bir kes cezasını mutlaka görecektir.

\section{Muhammed Peygamber}

Peygamberlerin sonuncusu, filozof, yiğit savaş ağası, İslam'ın kurucusu, yüksek ahlaklı Hz.Muhammed (sav) Mustafa'dır. Onun yüksek ahlakı Kuran-ı Kerim'de Kalem Suresi'nin 4. ayetinde de şöyle bildirilmektedir: "Sen elbette yüce bir ahlak üzeresin".

Kutsal Kitabımız Kur'an-ı Kerim'in Hz. Muhammed'e vahyedildiği iyi bilinmektedir. Kuran-ı Kerim'de Hz.Muhammed'in adı birkaç ayette geçmektedir. Mesala, Al-i İmran Suresi, 144; Ahzab Suresi, 40; Muhammed Suresi, 2; Fetih Suresi, 29. ayette geçmektedir. Muhammed Mustafa daha çok islam dininin promosyonu ile tanınmış hafızalara yazılmıştır.

Peygamberle ilgili konulara sadece Kuran-ı Kerim'de ve hadislerde değil, aynı zamanda folklor metinlerinde de rast geliyoruz. Sözlü halk edebiyatında Hz. Muhammed'in (sav) adı geçen bir kaç örneğe bakalım. Öncelikle dualara bakalım: mesela, adı Muhammed olana şöyle diyorlar:

Adın Muhammed peygamber sene kömek olsun.

Bu dua, eski Türk eseri "Divani-lüğat it-Türk"de de kullanılmıştır. Antik çağlardan beri halkımızın dilinde kullanıldığı anlaşılıyor. Bu sözlükten bir örnek:

Muhammed Mustafa yardımcın olsun (Şükrü. 2004, 667).

“Abbas ve Gülgez” destanından okuyoruz:

Kalmışdım keri-zeminde,

Cuşime bir nida geldi.

Oyandım hab-gafletden,

Muhammed Mustafa geldi (Azerbaycan destanları. 2005, 147).

Halk arasında inanca göre nazarı önlemek için üzerlik yakılır. Bu sözler söylenilir:

Çıkdım Savalan dağına,

Çağırdım ya Eli, ya Muhammed.

Dedi: nedir, biçare?

Dedim: bu derde çare.

Atın ağdır, üzerlik,

Donun ağdır, üzerlik,

Çetin işim düşübdür,

Hav günümdür, üzerlik.

Üzerliyi ekibdir,

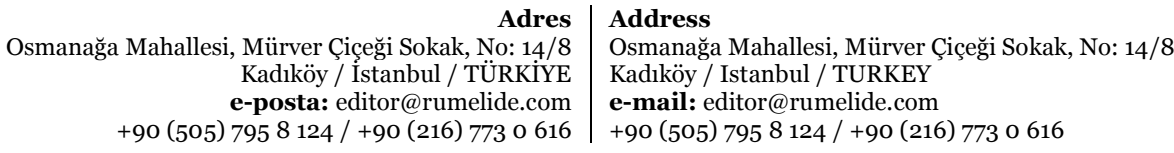


Hesen, Hüsen, Mustafa.

Kadasını savıbdır

Muhammed El Mustafa.

Üzerliyim çırtdasın,

Yaman gözler partdasın (Ceferli vd. 2011, 64).

Bu örnekte Muhammed peygamberin ve imamların ismi çekiliyor.

İnanca göre el arasında adamın, boğazı geldiği zaman şöyle derler:

Allah, Muhammed, Eli,

Ya İmam Hüseyn...

Gece gelmisen, gece get,

Gündüz gelmisen, gündüz get.

Heç, puç (bir şille), 3 defe tekrar olunur (Ceferli vd. 2011, 87).

Türkiye halk edebiyatına da Muhammed Mustafa'ya atıfta bulunan bir dizin güzellikler yansımıştır. Mesela:

Yedi kat gökleri seyran eyleyen,

Kürsinün üstünde cevlan eyleyen,

Mi'racında ümmetini dileyen,

Adı güzel, kendü güzel, Muhammed (Şükrü. 2004, 37).

\section{Sonuç}

Örneklerden de görüldüğü gibi, folklorda peygamberlerle ilgili konular çoktur. Ve bunun çok olması folklor metinlerini zenginleştiren ve ağırlıklarını arttıran detaylardandır. Araştırmaya dayanarak, folklor metinlerinde kullanılan bu konuların birçoğunun gerçek olduğunu söyleyebiliriz. Yani her peygamberin özellikleri ve yetenekleri olduğu gibi yansitılıyor. Bu, Allah'ın elçisi denilen peygamberler hakkındaki bilgilere atalarımızın ve ninelerimizin sahip olmasını, onlara olan inamın, sevginin ve güveninin bir göstergesidir.

Aynı zamanda gerek dinin, gerekse de her biri tarihi birer şahsiyet olmaları bakımından tarihin dedelerimizin hafızasında kök salmış hikayelerin söz varlığımıza transformasyon edilmesine sebep olmuştur. Tektanrıçllık dinine inanan Türk halklarının Allah'ın peygamberlerine olan inamı, güveni folklor metinlerinde yeteri kadar peygamberlerle ilgili örneklerin ortaya çımasına vesile olmuştur.

\section{Kaynakça}

"Azerbaycan vikimediaçları" istifadeçi grupunun resmi vebsaytı https://az.wikipedia.org/wiki/Ad\%C9\%99m Erişim tarihi: 15 nisan 2020

Altuntaş H., Şahin M. (2011). Kur’an-ı Kerim meâli. Ankara, Yenigün Matbaacılık

Azerbaycan destanları (2005). C. 2; 5 Bakı: Lider

Ceferli M. ve Babayev R. (2010). Nahçıvan folklor antologiyası. C. 1. Nahçıvan: Ecemi.

Ceferli M., Seferov Y., Babayev R. (2011). Nahçıvan folklor antologiyası. C. 2. Nahçıvan: Ecemi.

Ceferli M. ve Babayev R. (2012). Nahçıvan folklor antologiyası. C. 3. Nahçıvan: Ecemi.

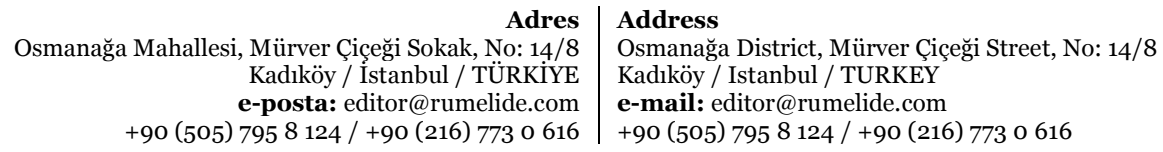


Ceferova A. (2012). Azerbaycan folklor antologiyası, XXIII kitab. (Nahçıvan örnekleri) C. 2. Bakı: Elm ve tehsil.

Dinimiz islam. http:// www.dinimizislam.com/detay.asp?Aid=3781 Erişim tarihi: 15 nisan 2020,

Orucov A. vd. (2006). Azerbaycan dilinin izahlı sözlüğü. C. 3 Bakı: Çırak. 